From: David Brown and Alistair J. K. Shepherd

The Security Dimensions of EU Enlargement: Wider Europe, Weaker Europe?

Manchester University Press (2007)

ISBN 978-0-7190-7280-2

\title{
Chapter 12 \\ EU Enlargement and security in the Mediterranean region
}

\section{Roderick Pace}

The EU's fifth enlargement, comprising eight CEE countries and the two Mediterranean island states of Cyprus and Malta, extended the Union's frontiers southwards towards North Africa and further eastwards towards Russia. While, in theory, an enlarged Union has more resources at its disposal to deal with its security challenges, in practice, the larger number of member states makes consensus more difficult. Member states also tend to prioritise issues closer to them geographically, which, in turn, influences the manner in which they view the Union's security challenges. As such, it produced an increased preponderance of CEE states in the EU, thus shifting the Union's internal balance and raising the possibility of the EU becoming more focused on the problems of Eastern Europe, at the expense of the Mediterranean region.

However, there is no compelling evidence that the EU is neglecting the Mediterranean region. In fact, it is practically impossible for the EU to do so. Firstly, the EU has a long Mediterranean coastline. Seven of the current EU member states - Cyprus, France, Greece, Italy, Malta, Spain and Slovenia - are situated on the Mediterranean Littoral. Portugal, whose coastline lies entirely on the Atlantic seaboard, is included, due to its cultural affinities with and geographic location in the Iberian Peninsula. Secondly, since the region is an important source of petroleum and gas supplies, it is of strategic importance to the EU and helps the EU counter the possibility of becoming overly dependent on Russian supplies. Thirdly, unresolved problems in the region, particularly the Middle East question, raise tensions that threaten the EU's own stability and its policies in the region. Last but not least, threats such as illegal immigration, terrorism and WMD proliferation, evident in the wider Mediterranean area, constitute direct and immediate challenges, which the EU has no option but to face up to.

The EU's main policy instrument in the Mediterranean region is the EuroMediterranean Partnership (EMP), launched in Barcelona in 1995. ${ }^{1}$ In fact, enlargement also changed the internal equilibrium within the EMP. Before enlargement, the EMP consisted of fifteen EU states and twelve Mediterranean partners. Now it consists of twenty-five EU states and ten partners, eleven if Libya eventually accepts the full EMP acquis. ${ }^{2}$ Cast into the 'EU Civilian Power' mode, it aims to create a Euro-Mediterranean area of shared prosperity by establishing a Euro-Mediterranean Free Trade Area (EMFTA) by 2010, by establishing a common area of peace and security, by developing human resources, by enhancing the understanding between cultures 
and by promoting exchanges between civil societies. The original aim was to achieve parallel progress in all three baskets - economic, political and cultural - which would be mutually reinforcing.

It is worth exploring these baskets in a little more depth. In the economic area, the establishment of the EMFTA requires bilateral free trade accords between the EU and each of the Mediterranean states and free trading arrangements amongst the non-EU Mediterranean states. These should be accompanied by the uniform application of the Community's competition rules, a common system of rules of origin and the application of the principle of cumulative rules of origin to facilitate trade and encourage further south-south integration. The bilateral EU accords are almost complete, with only the Association Agreement with Syria outstanding. The Agadir Free Trade Area (AFTA), involving Egypt, Morocco, Tunisia and Jordan, has led to a limited amount of southsouth economic integration. However, its implementation in practice, including the removal of tariff and non-tariff barriers to trade, is difficult to assess, as the information on implemented measures is limited. In addition, there are no visible signs that this initiative can be extended to the remaining EMP non-EU partners before 2010, when the EMTFA is supposed to be completed.

The political and security goals in the Barcelona Declaration included strengthening the rule of law and democracy, respect for human rights and fundamental freedoms, the right to self-determination, non-interference in internal affairs, the peaceful settlement of disputes, the preventing and combating of terrorism and thefight against organised crime. The 'hard' security issues identified were WMD proliferation, arms control and disarmament, accompanied by verification methods to ensure compliance. The EU and its partners agreed to establish weapon-free zones, particularly an 'effectively verifiable Middle East Zone free of WMD'. ${ }^{3}$ Finally, Euro-Mediterranean partners agreed to consider any confidence and security-building measures to create a Mediterranean area of peace and stability. The EMP's third basket focused on social, cultural and human affairs. A central component was cultural and religious dialogue, incorporating elements of civil society. Social and migratory issues also fell under this heading, as did the Euro-Mediterranean Parliamentary Forum. In 2005, this developed into a Euro-Mediterranean Parliamentary Assembly, composed of national parliamentary representatives from the EU member states and their Mediterranean partners, as well as the European Parliament.

The EMP is connected to the ENP, launched in March 2003 on the initiative of then Commission President, Romano Prodi. ${ }^{4}$ The ENP is a global strategy framework, offering advantages in the longer term to Russia, the western FSU and the states of the southern Mediterranean following enlargement. Its objectives are 'to share the benefits of an enlarged EU with neighbouring countries in order to contribute to increased stability, security and prosperity of the EU and its neighbours' and to offer the EU's neighbours 'the prospect of an increasing close relationship ... involving a significant degree of economic integration and a deepening of political cooperation'. It is based on the 'shared values' of liberty, democracy, respect for human rights and fundamental freedoms and 
the rule of law. ${ }^{6}$ The EU has also created a single Neighbourhood Financial Instrument to replace the existing financial instruments extending aid to the neighbouring states. However, was the ENP subsuming the EMP? In reality, the EMP is still operational but, for the more ambitious Mediterranean partners, there is the prospect of a deeper bilateral relationship with the EU on the basis of Action Plans, negotiated bilaterally under the ENP. These Action Plans, tailor-made to each partner's particular needs, can lead to increased access to the Single Market and to wider economic benefits, should the partner achieve all its agree aims. Thus, the ENP can act as a driving force for the EMP.

The manner in which the ENP and the EMP help the EU attain its security aimsin the Mediterranean region are analysed further in this chapter. In addition, it is worth keeping in mind that the EU is not the only major actor in the Mediterranean region. It should be remembered that the US, the Union's Mediterranean partners and some of the larger EU member states themselves pursue their own national objectives in this region, while NATO established its Mediterranean Dialogue in 1994. This chapter will address the main security challenges faced by the EU in the Mediterranean region and the effectiveness of EU policies in dealing with them. Mindful of the array of threats the EU faces in the region, this chapter narrows the focus to a select few. These are security of energy supplies, illegal immigration, terrorism and the Middle East conflict and WMD proliferation. It also deals with the advantages and pitfalls of the Union's soft or 'civil' power approach. The EU has traditionally behaved as a 'civilian power' in the Mediterranean region, but its policies have tended to suffer from the divided attention of the EU member states, their often conflicting interests, the weak involvement of the EU's Mediterranean partners in the decision-making structures, their reluctance to adopt a self-help mentality and their lack of enthusiasm to fully implement agreed measures. However, to begin with, it is necessary to briefly sketch out some of the major security concerns facing the EU in this area, as noted above.

\section{EU energy dependence}

The EU's priorities in the region have changed in line with changing geo-political situations but, in recent years, it is terrorism and the security of energy supplies which have become the dominant issues. In the energy field, the EU is heavily dependent upon fossil fuels, over half of which are imported. About 46 per cent of oil imports originate in Russia and Norway, while slightly less than a third come from the Arab World. ${ }^{7}$ According to the 2000 Green Paper, 'Towards a European strategy for security of energy supply', the EU imports 30 per cent of its gas from Algeria and a quarter from Norway. ${ }^{8}$ Relations with the Gulf States and the wider Mediterranean are thus as crucial as the EU's relations with Russia and the oil rich republics around the Caspian Sea. The Arab states' importance is expected to grow as the EU's external dependence on energy supplies increases. The Green Paper estimates that if, by 2030, no marked shift to alternative energy sources occurs, the EU's external dependence will reach 90 per cent for oil and 80 per cent for gas. The geo-political implications 
of these developments explain the Union's eagerness to maintain strong relations with the Arab world and secure a lasting solution to the Middle East conflict, given its stabilizing effect on the wider region. Algeria's gas supplies are also crucial in lessening the EU's dependence on Russia, as demonstrated in the January 2006 gas crisis. Gas and oil exports constitute more than 90 per cent of Algeria's exports to the EU. Algerian low sulphur oil is also crucially important to European refineries eager to observe strict EU environmental rules. ${ }^{9}$

\section{Illegal immigration}

Another major security challenge is that posed by illegal immigration. The phenomenon comprises different categories of people requiring responses that straddle traditional security policy divisions. It involves economic refugees and genuine political refugees fleeing instability, mostly from sub-Saharan Africa. Europol claims that organised crime organisations have taken over migration flows in the Mediterranean region, raising the possibility that such networks could combine with traditional criminal activities, such as illicit arms and drug trafficking or terrorist penetration of the EU. ${ }^{10}$ Europol stresses that many of the traditional transit countries that joined the EU in 2004 are now, more than before, targeted as destination countries by the facilitators of illegal immigrants. These facilitators, already well established in those states, utilise the fact that the new control systems in the enlarged EU are not yet running smoothly. Furthermore, the EU's borders are now closer to many key source and transit countries.

The complexity of moving large volumes of people across long distances requires a degree of organisation, specialisation and sophistication that can only be met by organised crime groups. ${ }^{11}$ A number of examples demonstrated the scale of the potential problem. For example, the EU's southern member states, particularly Spain, Portugal, France, Italy, Malta, Greece and Cyprus, are in the forefront of the 'Mediterranean Boat People' crisis. ${ }^{12}$ This raises a number of issues, such as the humanitarian treatment of migrants, the maintenance costs incurred until they are re-settled or repatriated and the level of co-operation, or lack of it, shown by the countries of origin, which have little incentive to stop the illegal flows or to readmit illegal immigrants. In addition, in the wake of incidents in Cueta and Mellila in September 2005, when dozens of illegal immigrants were killed or injured as they tried to storm the barriers separating the two Spanish enclaves from Moroccan territory, Spain called for a Euro-African Summit, a call endorsed by France at the 2005 Franco-Spanish summit. ${ }^{13}$ In the central Mediterranean, Libya has become a destination country for illegal immigrants, mostly from sub-Saharan Africa, and a transit point to Europe. The EU mission to Libya

estimated that there were between 0.75 and $1.2 \mathrm{~m}$ illegal immigrants in Libya. ${ }^{14}$ Libya shares some $4,400 \mathrm{~km}$ of border with six states, including three poor and unstable subSaharan states, namely Sudan, Chad and Niger. Its Mediterranean coast is 1,770 km long, which adds to the difficulty of 
precluding clandestine boats from embarking on their trip to Malta and Italy, particularly to the islands of Sicily, Pantelleria and Lampedusa.

\section{Terrible twins: terrorism and the Middle East conflict}

The end of the Cold War has not led to significant positive shifts in the region's main conflicts. The rise in terrorist activity, particularly since September 11, is a significant problem. Excluding casualties in Iraq, the total number of deaths from terrorism in the Near East was 726 in 2004, compared with 636 in Europe and Euro-Asia combined. ${ }^{15}$ Terrorism is often linked with the Mediterranean region, because of associations - accurate or otherwise - with Islam, although Muslim leaders rightly insist that the association is false. The other destabilising problem is the Middle East conflict, which affects relations in the entire region and has led to increased terrorist activity. The EU rightly insists on the need for north-south co-operation in countering terrorism, although such co-operation is not easy. Major differences have emerged regarding acceptable definitions, with certain Arab states reluctant to designate organizations such as Hamas or Lebanese Hezbollah as terrorist groups, while the EU includes both in its list of terrorist organisations. ${ }^{16}$ Hamas won the local elections in the Palestinian territories held in December 2005 and has overtaken Fatah as the main Palestinian political force, following the 2006 parliamentary elections. This result makes it considerably more difficult for the EU to argue that it would not have direct contact with Hamas, who now possess a democratic mandate to govern. The first signs - in terms of continued aid, while still insisting on a Hamas commitment to end all violence - suggest that the EU's preference would be to find some way to engage all actors in the wider conflict. In addition, it should be remembered that, despite the enormity of the definitional gap that exists between the EU and its Middle Eastern counterparts, such difficulties have not been permitted to fully obstruct practical anti-terrorist co-operation in many areas.

However, the lack of a common definitional basis is not the only concern in operationalising counter-terrorist co-operation within the wider region. As part of the 'Waron Terror', certain governments have been perceived as being prone to restricting civil liberties, often disregarding international human rights conventions and the obligations they impose on them. This is despite the fact that such repressive action is often blamed for encouraging extremism and terrorism. Certain states, in effect, 'took advantage' of their anti-terror laws to strengthen their hold on power. For example, in Tunisia, a 2003 anti-terror law contains a broad definition of terrorism, which could be misused to prosecute persons for the peaceful exercise of their right to dissent, and outlines harsh penalties, including the referral of civilian suspects to military courts. ${ }^{17}$ Human rights activists have also been harassed in Tunisia. ${ }^{18}$ Human rights NGOs report similar developments in other Middle Eastern and North African states. In 2004, back sliding on human rights, resulting from counter-terrorist actions, also became evident in Morocco, which had previously been considered to be one of the more advanced promoters of such rights. ${ }^{19}$ Given the EU's high-profile advocacy of 
human rights and the civil liberties agenda, such developments are potentially troubling for developing co-operation.

The Middle East problem injects political and economic uncertainty throughout the Mediterranean region. The diplomatic efforts of 'The Quartet' (the US, the EU, Russia and the UN) are focused on finding a lasting solution, while Palestinian reform and the Israeli withdrawal from Gaza and possibly parts of the West Bank offer a glimmer of hope. However, at the time of writing, the region was plunged into a further bout of political uncertainty, following the rapid establishment of Kadima, the tragic stroke that debilitated Israeli Prime Minister, Ariel Sharon, and the aforementioned Hamas victory. As a result, the 'road map' to peace is out of sync. That said, on 20 December 2005, UN Under-Secretary-General for Political Affairs, Ibrahim Gambari, informed the UNSC that the plan is still the agreed framework for reaching lasting peace in the Middle East. ${ }^{20}$ Apart from its involvement in 'The Quartet', the EU has shown its readiness to become involved in a practical manner in helping solidify peace. On 14 November 2005, the Council established an EU Police Mission in the Palestinian Territories (EUPOL COPPS), which aims to provide enhanced support to the Palestinian Authority in establishing sustainable and effective policing arrangements. ${ }^{21} \mathrm{~A}$ day later, Israel and the Palestinian Authority concluded an 'Agreement on Movement and Access', establishing agreed principles on the Rafah crossing pointing. This enabled the EU to undertake the third party role proposed in the Agreement and to launch the EU Border Assistance Mission at the Rafah crossing point. Terrorism and the Middle East conflict are also the two most potent obstacles to much-needed reform in the region. The 2003 Arab Human Development Report observes that regressive governments in the Arab world 'have found a new justification (terrorism) for their ongoing warnings about the perils of freedom'. ${ }^{22}$ It also noted that 'the occupation of Palestinian and other Arab lands exerts a direct and continuous burden on the economies of affected countries and diverts resources from development to military and security objective'. ${ }^{23}$ Furthermore, although the Middle East problem does not fall directly under the EMP's purview, it has, in effect, obstructed the development of a security dialogue, leading to the abandonment of The Charter for Peace and Stability, which was supposed to be the main achievement in the political basket. In addition, while the Middle East conflict continues to dominate the agenda, lesser long-standing conflicts and tensions cannot be ignored. These include tensions over Cyprus, traditional Greek-Turkish rivalry in the Aegean and intra-Arab tensions, such as those between Morocco and Algeria over the Spanish Sahara. This has poisoned efforts towards the realisation of an 'Arab Maghreb Union', which would have contributed significantly towards realising the EMFTA by 2010.

\section{Weapons of mass destruction}

In a 1996 RAND study, Lesser and Tellis painted a bleak picture of the scale and likely development of WMD proliferation in the Mediterranean region. They concluded that 
nowhere was the prospect of the spread of WMD likely to have a more pronounced effect on strategic perceptions than around the Mediterranean, given that many of the world's leading WMD proliferators are arrayed along Europe's southern periphery. They observed that key states south and east of the Mediterranean either possessed or were in the process of acquiring WMD, along with the means for delivering them across the Mediterranean. At the time, they singled out Egypt, Iran and Iraq as having the capability of developing long-range missile technology, claiming that Egypt also had active chemical-weapons and long-range missile development programmes. The report claimed that Libya and Syria possessed chemical weapons (Libya also had a biological capability), and that Algeria had been pushing ahead with development of a nuclear infrastructure. One important conclusion was that, within ten years, it was possible that every southern European capital would be within range of ballistic missiles based in North Africa or the Levant, with Turkish population centres already exposed to missiles based in Syria and Iran (and, at the time, Iraq). ${ }^{24}$

Since the publication of the RAND report, the situation has improved marginally in some cases and regressed in others. The military occupation of Iraq and Libya's decision to dismantle its WMD programmes effectively 'neutralised' two states known to be pursuing or which had the potential to pursue such programmes. Significantly, these developments did not result from the EU's Mediterranean policies, but from the AngloAmerican intervention in Iraq. As Michele Dunne argues, Libya's change of heart on WMD was influenced by the US led 'War on Terror' and the looming war in Iraq, which raised fears in Tripoli that 'it was in the sights of influential neoconservatives in Washington'. ${ }^{25}$ That said, in fairness, mention must be made of France, Germany and the UK's efforts, supported by the rest of the EU, in pressurizing Iran to dismantle its programme to produce nuclear weapons grade material, a matter of continuing controversy at the time of writing. Iran's military programmes are a threat not only to stability in the strategically important Gulf and Middle Eastern regions, but also, potentially, to the EU. According to Guy Bechor, Iran is developing the Shihab-4 missile, successor to the Shihab-3, while Syria, aided by North Korea and Iran, is reported to be sharpening the accuracy of its SCUD D missiles. With a range of $650 \mathrm{~km}$, these can reach most of Turkey and Cyprus, the outer fringes of Greece, as well as neighbouring states. ${ }^{26}$

Part of the problem in this area is that the technology is not difficult to attain.States may acquire it independently or by procuring it from other states, as the 2004 Abdul Qadeer Khan affair showed. Many states can supply nuclear reactors and technology initially for peaceful uses, which is considered to be the first step in building a military programme, as has been seen in the debate over Iran's longer-term intentions. Argentina has built a nuclear reactor in Egypt, which could enable it to build one bomb a year. ${ }^{27}$ Egypt has not yet acquired nuclear weapons, and has so far been largely compliant with IAEA requirements. However, it has failed on a number of occasions to report some nuclear activities (albeit involving only small quantities of nuclear material), in accordance with its obligations under the NPT Safeguards Agreement. ${ }^{28}$ In 2002, it was reported to be considering developing a uranium enrichment plant with the help of China. ${ }^{29}$ Egypt and Israel have not ratified the Nuclear 
Test Ban Treaty: Egypt claims that it would ratify it only if Israel accepted the NPT. Most Muslim countries in the Middle Eastern region claim to support the creation of a WMD-free Middle East zone and are ready to halt their own WMD programmes, on condition that Israel removes its atomic weapons. As a rule, compliance with international conventions in the Mediterranean region is generally weak: Iraq and Libya are known to have violated the NPT; Egypt, Lebanon and Syria have not signed the Chemical Weapons Convention (CWC); Israel signed the CWC, but has not ratified it and has not signed the 1972 Biological Weapons Convention.

\section{The struggle for resources}

Very serious tensions, possibly leading to conflict, may arise as a result of the struggle for resources, involving water and fisheries, as well as offshore rights to prospect for oil and gas. Due to the narrowness of the Mediterranean Sea, only Cyprus has declared a 200 nautical mile exclusive economic zone (EEZ). Spain, France and Morocco apply such zones on their Atlantic coastlines, but not in the Mediterranean. Lack of agreement over the delineation of the continental shelf involves nearly all the Mediterranean countries, particularly Italy, France, Spain, Libya, Tunisia, Malta, Morocco, Greece and Turkey. ${ }^{30}$ This presents serious obstacles to gas and oil explorations in contested regions. As world demand for energy resources rises and economic growth in the Mediterranean shore states increases, impacting further on their consumption of fossil fuels, these territorial issues become more crucial. Another contributory factor has been the development of deep-sea drilling, which brought potentially oil and gas rich, but hitherto inaccessible, areas within reach. Water resources present another problem. Roberto Aliboni observed that, in the early 1990s, several Mediterranean leaders referred to the scarcity of water as a potential trigger for war in the region. ${ }^{31}$ Economic growth and the demographic explosion are making the problem even more acute. Aliboni summarises the situation around key rivers in the Mediterranean region thus: disputes over the Nile involve eight countries, notably Egypt and the Sudan; the Jordan river dispute involves Israel, Jordan and Syria; the Tigris-Euphrates river system involves Turkey, Syria and Iraq. Aliboni concludes that, while water may not be regarded as a direct cause of conflict, water disputes and the lack of solutions to the problem could worsen already tense relations.

In the case of fishing resources, it is noteworthy that, in 2005, both Tunisia and Libya extended their 'exclusive fishing conservation zone' beyond their territorial seas, bringing to five the number of states that claim such a zone. ${ }^{32}$ The others are Algeria (1994), Malta (1978) and Spain (1997). ${ }^{33}$ The Libyan zone starts above a straight line drawn from Misratah in the west to Benghazi in the east, effectively designating the Gulf of Sidra as internal Libyan waters. This pushes Libyan control over an area considered to be international waters. ${ }^{34}$ The extended Tunisian fishing zone engulfs the small Italian isles of Pantelleria and Lampedusa, stopping about fifteen nautical miles from their coastlines. ${ }^{35}$ The declaration of these fishing zones gives 
their respective states control only over fishery resources. However, tensions arise when fishermen of other nationalities are deprived of their traditional fishing grounds. Lesser Mediterranean tensions have also erupted suddenly around tiny rocks and atolls. These mostly uninhabited rocks are pivotal in the delineation of both EEZs and the continental shelf. Nearly all the states of the Mediterranean region, with the exception of Malta and Tunisia, have unresolved land border issues with their neighbours. The best-known ones are those involving Spain and the UK over Gibraltar, which finds its replica in Spanish Moroccan relations over Spain's North African enclaves of Cueta and Mellila. In July 2002, Spain sent troops to the disputed and deserted, half-a-mile-long island of Perejil (or Leila, as it is known in Morocco), after Moroccan soldiers had landed on it. ${ }^{36}$ The island, situated around 200 meters from Morocco's shore, had not been formally claimed by Spain until then. This incident was reminiscent of the 1996 Imia (Turkish Kardak) affair that forced the US to broker a Greek and Turkish military withdrawal from a group of uninhabited islands in the Aegean that were claimed by both. ${ }^{37}$

\section{Responding to the security challenges in the Mediterranean}

The security challenges the EU faces in the Mediterranean region require a combination of responses, embracing economic, political and military options. Lacking the necessary military means, the EU has traditionally relied on its economic strength and market size, acting as a 'civilian power'. Before considering the development of EC/EU political involvement in the region, there are a number of general concerns to be noted. For example, the EU and the US concur on the promotion of democracy in the Mediterranean region, though both are occasionally ambivalent as to the levels of pressure to be applied, depending on their differing interests. The EU and the US garb their foreign policy objectives in idealistic terms, ostensibly to encourage more peaceful inter-state relations, but, in doing this, they also 'promote substantive interests'. 38 Citizens in the Arab world are also aware that Western governments support existing authoritarian regimes, while pressing for democratic reforms, a case of double standards. In addition, the EU's Mediterranean partners perceive democracy in terms of its impact on their regime's survival and can therefore be reluctant to promote far-reaching democratic reforms.

Additionally, EU policy has often suffered from a lack of agreement among its own member states. For example, French support for the Algerian government during the civil war, which started in 1992, obstructed the emergence of a coherent EU response. ${ }^{39}$ US policies in the region often have a similar effect. For example, Washington's rapprochement with Libya appears not to include stringent conditions on the improvement of democracy and human rights. As this is a central EMP requirement, it may help explain why Libya has been slow to commit itself as a fully fledged partner as yet. Furthermore, the US is pursuing the 'Greater Middle East Initiative' in the Mediterranean region and beyond, concluding free trade agreements with a number of 
the littoral states. ${ }^{40}$ The latter agreements do not pose real economic threats to the EU. In fact, they could be helpful if they catalyse economic growth in these states. However, they may also dilute the EU's leverage over its Mediterranean partners.

Before assessing the detail of the EMP, it is worth placing the developments in some form of historical context. The EC's engagement as a 'civilian power' in the Mediterranean region began when it concluded Association Agreements with Greece and Turkey (1961-63), a process it has continued with most of the other Mediterranean states. In 1972, the EC launched a more streamlined Global Mediterranean Policy (GMP) and proceeded to extend formal preferential trading arrangements with all the Mediterranean states. However, the GMP and other EC/EU initiatives have had to adjust to new challenges emanating from the region, often leading to the impression that it is more spectator than participant in the events of the wider region. While the GMP was useful in consolidating the traditional regional trade patterns, thus strengthening interdependence between the two shores of the Mediterranean region, in the political domain the EC fared less well. For example, the Euro-Arab Dialogue, which the EC had helped establish in 1975, despite Washington's objections, died prematurely following the 1979 EgyptIsrael Camp David Accord and the internal divisions this provoked in the Arab world. The EC's perceived leanings towards the Arab World and its 1980 Venice Declaration on the Middle East led to a deterioration of its relations with Israel. ${ }^{41}$

As a result, the member states tended to venture no further than to issue periodic declarations on their major concerns, often with great difficulty and after a lot of internal wrangling. To use Ambassador Ischinger's distinction, applied in the context of the EU's current policy dilemmas, it developed a 'declarative', as distinguished from an 'operational', foreign policy, earning it the frequently applied epithet of being 'an economic giant but a political pygmy'. ${ }^{42}$ The EU has found it difficult since to shake off this derogatory image. In fact, various non-EU initiatives, such as the 'Five plus Five' arrangement in the Western Mediterranean, the Mediterranean Forum and NATO's Mediterranean Dialogue, had already made a modest start before the EU even launched EMP in November 1995. Kagan has likened the EU's current foreign policy to the chorus in a classical Greek tragedy: 'It comments on the action. It reacts with horror and praise. It interacts in various ways with the protagonists. But the singers themselves play no part in the plot. ${ }^{43}$ The conclusion to be drawn is that a 'civilian power' approach on its own was often insufficient to handle the security challenges it faced. Lacking the unified military capabilities, the strength and diplomatic prestige of the US, and relying primarily on its soft power approach, the EU could not assume a leading diplomatic role in the region. These developments help expose the limits of the 'civilian power' approach.

\section{The success and failures of the EMP}

When the EMP was launched in 1995, the Middle East problem was purposely left out of its purview because of its disruptive potential, although it was thought that the 
EMP would help strengthen the broader conditions for a lasting peace in the region. However, it made the security dialogue within the first basket of the Barcelona process more difficult. Symptomatic of this was the fact that the proposed Euro-Mediterranean Charter for Peace and Stability had to be abandoned after years of almost complete stalemate. Senior officials of the EMP had begun to draft the Charter after the 1995 Barcelona meeting. In 1997, the Ministers agreed that work on the Charter should continue 'in order to submit as soon as possible an agreed text for approval at a future Ministerial Meeting when political circumstances allow' (emphasis added). ${ }^{44}$ Representatives of the Arab states had decided that they would not approve the Charter before the Middle East problem had finally been resolved. Human rights, democracy and the rule of law are emblematic of the EU's overall approach. They are stressed in all EMP Ministerial declarations, are regularly cited by the European Parliament in its resolutions ${ }^{45}$ and emphasised by the Commission, which noted the importance of 'mainstreaming' human rights in the EU's external relations. ${ }^{46}$ Such issues also play a pivotal role in the Commission's EMP work programme, submitted in April 2005. ${ }^{47}$ Human rights clauses have been inserted in EC/EU agreements with non-member countries since 1989. Consistent with this policy, a 'political conditionality' or 'essential element clause' became a basic feature of all EMP Association Agreements. Such clauses were intended to help the EU pursue a positive engagement on reform with Mediterranean non-member states. This noncoercive approach, together with the EU's self-imposed limitation of issuing demarches, in preference to suspending the Association Agreements' provisions, has prompted criticism that the EU's human rights policy in the Mediterranean is ineffective. ${ }^{48}$ Such criticism has wider implications, as the promotion of democracy and human rights is also important to the EU's 'civilian power' approach.

As Youngs argues, the EU's 'non-coercive' approach is a deliberate one, because the EU prefers 'positive engagement' and 'partnership'. ${ }^{49} \mathrm{He}$ describes European approaches, at both the regional and national level, as 'socio-economic, technogovernance [in] character, combining relatively innocuous grassroots initiatives with top-down cooperation purporting to "nudge" unthreateningly the outlooks of theentrenched elites. ${ }^{50}$ The European Council claims that the EU aims to be a convincing rather than an imposing power, with engagement and dialogue as the preferred meansof interaction with third countries. The EU:

has to seek a balance between persuasion and critical action. Promoting human rights involves building relations of trust, having a genuine exchange of views, setting conditions for fruitful cooperation and offering assistance to meet them, but being willing to indicate clearly when red lines have been crossed. ${ }^{51}$

Indeed, in contrast to the criticism of the EU as essentially passive (noted earlier in the chapter), Madeleine Bunting has praised this non-coercive approach, claiming that the costs in changing Iraq seem to be swaying opinion against the use of force as an instrument of change, towards the peaceful European approach. ${ }^{52}$ Yet, how can EU policy effectiveness be increased? Youngs stresses that the EU's highly formalised and institutionalised partnerships tend to work to their own internal momentum, isolated 
from outside events. EU policies must, therefore, be more alert to grasp the opportunities that present themselves for promoting human rights.

Mainstreaming human rights in the EU's external relations has led to calls for the involvement of Euro-Mediterranean civil society and other initiatives, such as a dialogue of civilisations and the Euro-Mediterranean Parliamentary Assembly. A modest financial outlay to support NGOs and the promotion of democracy and human rights was established in 1999, when, on the insistence of the European Parliament, the European Initiative for Democracy and Human Rights (EIDHR) was created. Currently, it has an annual outlay of approximately $€ 100 \mathrm{~m}$, to support human rights, democratisation and conflict prevention activities. The supported programmes are to be carried out in partnership with NGOs and international organisations. In contrast to the task it confronts, which may have worsened in the era of the 'War on Terror' (as noted earlier), such a figure is not extensive, though nevertheless helpful. The magnitude of the task of effectively promoting human rights and democracy in the Mediterranean region is such that it can only be accomplished if supported by stronger policy instruments, such as a democracy clause, accompanied by an EU readiness to invoke it appropriately.

The promotion of civil society projects and its wider involvement in the EMP raises a number of other issues. Civil society in the majority of the EU's Mediterranean partners mainly consists of NGOs that have emerged within the framework of semirestrictive laws on freedom of association. Many of these NGOs are not only permitted but also encouraged by their respective governments, in order to confront social problems that the states are unable to cope with. As Brumberg observes, many of these NGOs in the Arab World are the result of a deliberate policy of 'partial inclusion', whereby regimes extend recognition to a large number of NGOs, allowing the opposition to 'blow off steam', while withholding the freedom to more broadly based, popular movements that could seriously challenge their authority. ${ }^{53}$ Brumberg adds, 'for wily "reformists" such as Egypt's Mubarak, it is better to have 5,000 small civil society organisations than five big ones, since many competing NGOs impede social activists' cooperation'. ${ }^{54}$ More poignantly, Ottaway observes:

Political parties (in the Arab World) embracing democracy remain weak, their leaders isolated in downtown offices, while Islamist organisations set up headquarters in lowerclass sections of town. Pro-democracy intellectuals in general shun political parties and prefer to set up NGOs . . . These organisations can generate quickly visible activities, such as conferences and receive attention abroad. But these groups are not generally able to speak to the general public in their own countries . . . Ideologically, the Arab street belongs much more to the Islamist preachers than to democracy activists. ${ }^{55}$

Thus, a more productive civil society dialogue could only be achieved if non-official Islamist NGOs are successfully targeted. However, these are difficult to locate or engage, both because little is known about them and because such contacts are certainly to be obstructed by the government in question.

It seems that the EU's best chance of success is to encourage a 'top-bottom' reform process. The kind of democratic reforms that the EU wishes to encourage in 
the Mediterranean region are outlined in a Regional Strategy Paper and Regional Indicative Programme. ${ }^{56}$ Following this, a Country Strategy Paper and an associated National Indicative Programme (NIP) was negotiated with each partner state, detailing the reforms that each had to achieve. However, a 2004 report, evaluating the effect of the MEDA programme in Egypt found that the Union's strategy makes little explicit mention of other EU objectives, namely stability, based on democratization and conflict prevention. The same report states that the results achieved have been mixed, with the overall impact of such programmes limited by the slow pace of reform within Egypt. ${ }^{57}$ Such failures may help explain the European Parliament's request to be involved in the evaluation of the human rights assessments carried out by the Commission within the ambit of the ENP. ${ }^{58}$ The Commission has already set up human rights sub-committees, with a view to ensuring more commitment to reform.

Other potential improvements include improving the Mediterranean partners' joint ownership of the Partnership, in which the EU is still the main agenda setter. In addition, conflicting goals have often obstructed EU policy making and these must be ironed out. For example, securing the co-operation of the Mediterranean partners in implementing free trade seems to have diminished the EU's leverage to coax them towards deeper political reforms. The effectiveness of the EU can also be strengthened if the partners' economic dependence on the EU is substantive enough to make noncompliance costly. Increased financial aid to the Mediterranean partners, to help them overcome the problems of restructuring, particularly in the agricultural sector, may increase the attractiveness of compliance - and the cost of non-compliance. Effectiveness also requires coherence on the part of the EU member states and a willingness to act decisively. However, the resurgence of a petrodollar surplus in the Mediterranean region blunts the EU's economic instruments for inducing reform.

\section{Conclusion: EU security options in the Mediterranean region}

This chapter has focused on the main security challenges that the EU faces in the Mediterranean region. Enlargement has provided it with more assets to confront the 'arc of instability' that surrounds it, from the borders of Russia in the north to its southern frontiers in the Mediterranean region. Although the accession of Cyprus and Malta does not add, in a substantive way, to the assets and resources needed to confront these challenges, both states contribute towards increasing the EU's sensitivities in the region. Since both Cyprus and Malta are small island states, they tend to focus more on their immediate regional environment than on wider global perspectives. For this reason, and particularly if Cyprus manages to free itself from focusing almost exclusively on its internal problems, the two EU Mediterranean states can stimulate a stronger focus on Mediterranean issues within the main EU institutions.

The ENP is a welcome development, which, if properly implemented, could improve the functioning of the EMP, while increasing the EU's effectiveness in the Mediterranean region in a number of areas. However, a 'civilian power' approach on 
its own may not be sufficient and the EU needs to develop ESDP further, in order to offer a suitable response across the range of possible instruments at its disposal. At the same time, it is worth emphasising that the main challenges that the EU faces in the Mediterranean region cannot be solved by military means alone - if at all. Under the ENP, the Commission has prepared a number of country reports and, on this basis, Action Plans were negotiated with Israel, Jordan, Morocco, Tunisia and the Palestinian Authority, aiming to promote political and economic reform, as well as modernisation and development. ${ }^{59}$ On 21 February 2005, the European Council reached agreement on the positions to be adopted by the EU within the Association Councils and the EUPalestinian Authority Joint Committee to implement these Plans. Action Plans are also to be negotiated with Algeria and Egypt, as well as Lebanon once the situation improves. These Plans are careful to take into account the individual needs of each partner. The ENP offers rewards to all of the Union's partners that carry out the agreed measures, in terms of increased access to the internal market and Community programmes. Hence the effectiveness of this policy hinges on the correct evaluation of the Plans' implementation and the ability of the EU to take timely decisions. The European Parliament wishes to be involved - together with the Commission - in evaluating these Action Plans, while the Commission has appealed for continued and comprehensive support from the member states.

The purview of the ENP and the EMP is being extended, to include other matters, such as energy security, migration and WMD proliferation. However, it is short sighted to rely solely on this policy instrument. There is much to be developed on the EU side, which, in turn, will help reduce the Union's risks. For example, increased energy efficiency and the development of alternative energy resources helps to lessen the EU's external dependence and reduce risks in this sector. It also provides innovations that can be useful to the southern riparian states, in order to satisfy their increasing energy needs as they move up the development ladder. The promotion and implementation of democracy programmes attacks not only some of the root causes of terrorism, but also of illegal immigration. The promotion of the dialogue of civilisations, through such institutions as the Alexandria-based Anna Lindh Foundation, is useful, but its limitations must be equally recognised. The dialogue primarily involves elites, but civil society in the region cannot be ignored, for such a dialogue can be fully effective only if it filters down to the grass roots in the societies it is meant to influence.

Immigration is a good example of how internal and external EU policies need to be co-ordinated. It requires policy instruments beyond the ENP and EMP, securing compliance from the southern littoral states to take action to curb this phenomenon. It requires co-operation and co-ordination, as well as coherence, at an EU level and the sharing of information among EU member states on the basis of solidarity. Additionally, it depends on the readiness of the member states to combine their military assets, in order to safeguard security in their territorial waters, through adequate patrolling and help and rescue missions, and to prevent organised crime networks from carrying out their activities with impunity. Last but not least, it calls for a properly designed and implemented EU emigration policy. 
In the case of terrorism, tightening the network of collaboration and intelligence sharing amongst the EU member states and their Mediterranean partners is important. More useful will be the resolution of the older conflicts that fuel this phenomenon, primarily the Middle East problem and authoritarianism in key Mediterranean partners. Anti-terrorist measures in the EU's Mediterranean partners should not be allowed to strangle NGOs and individuals struggling for democracy. At the same time, terrorism must not be viewed as a threat to the EU, but as a common threat faced by all states. In combating terrorism, military means, under the aegis of the ESDP, can also become useful in failed states, in order to restore order and open the way to humanitarian efforts. As the EU itself recognises, regional conflicts need political solutions, but military assets and effective policing may be needed in the post conflict phase, such as the EU is doing in Gaza. Civilian crisis management helps restore civil government. The EU is particularly well equipped to respond to such multi-faceted situations.

Finally, in terms of WMD proliferation, the EU calls for the strengthening of multilateral non-proliferation regimes and verification methods, to ensure compliance, ${ }^{60}$ as well as the mainstreaming of non-proliferation policies into the EU's wider relations with third countries. This could be done by introducing a non-proliferation clause into agreements with these states. This proposal follows the path of the 'democracy' clause in the Association Agreements. Deeper scrutiny as to how this new conditionality will be implemented is required, in the light of the pitfalls in the implementation of the human rights and democracy conditionality identified in this chapter.

\section{Notes}

1 For details on the Euro-Mediterranean Partnership, see http://europa.eu.int/ comm/external_relations/euromed/bd.htm.

2 The ten partners are Jordan, Lebanon, Syria, Egypt, Tunisia, Algeria, Morocco and the Palestinian Authority, Turkey and Israel.

3 Euro-Mediterranean Partnership, The Barcelona Declaration and Work Programme (Brussels, 1995), pp. 137-8.

4 European Commission, Wider Europe - Neighbourhood: A New Framework for Relations with our Eastern and Southern Neighbours (Brussels, 2003).

5 See Conclusions of the 2590 General Affairs Council (Luxembourg, June 2004).

6 Council of the European Union, Conclusions of the Thessalonica European Council (Brussels, June 2003).

7 EU crude oil imports, as of 2004: Saudi Arabia 12.8 per cent; Libya 9.6 per cent; Algeria 3.7 per cent; Iraq 2.64 per cent; Syria 1.7 per cent; Kuwait 1.14 per cent; Egypt 0.5 per cent; Tunisia 0.34 per cent; Russia 25.9 per cent; Norway 20.02 per cent, www.europa.eu.int/comm/energy/oil/crude/index_en.htm.

8 European Commission, Towards a European Strategy for Security of Energy Supply (Brussels,November 2000).

9 For details on state profiles, see www.eia.doe.gov/emeu/cabs/algeria.html 10 Organised Illegal Immigration into the European Union (The Hague: Europol, 2005). 11 European Union Organised Crime Situation Report 2004 (The Hague: Europol, 2005), pp. 13-14. 
12 Philippe Fargues (ed.), Mediterranean Migration Report 2005 (Florence: European University Institute, 2005). He claims that statistical information on irregular migrants originating from the Mediterranean non-member states is almost non-existent.

13 'Immigration: initiative conjointe franco-espagnole auprès de l'Union européenne', Fenêtre sur l'Europe (18 October 2005), www.fenetreeurope.com/php/page.php?section_ actu\&id_4717.

14 European Commission, Technical Mission to Libya on Illegal Immigration 27 November to 6 December 2004 (Brussels, January 2005).

15 There is no reliable data on terrorist casualties in the Mediterranean region. The source quoted here is Paul Wilkinson, 'International terrorism: the changing threat and the EUresponse', Chaillot Paper, 84 (October 2005).

16 Council Common Position on the Application of Specific Measures to Combat Terrorism (Brussels, November 2005).

17 For details on Tunisia, see Human Rights Watch: World Report 2005, http://hrw.org/ english/docs/2005/01/13/tunisi9801.htm.

18 Tunisia: Intimidation of the Tunisian League for Human Rights Must Stop (London, Amnesty International, 2005).

19 Morocco: Human Rights at a Crossroads (London, Human Rights Watch, 2004), http://hrw.org/reports/2004/morocco1004/.

20 'Despite missed deadline, Quartet peace plan still valid, UN envoy', UN News Centre, 20December 2005, www.un.org/apps/news/story.asp?NewsID_16998\&Cr_Middle\& Cr1_East.

21 Council Joint Action on Establishing a European Union Border Assistance Mission for the Rafah Crossing Point (EU BAM Rafah) (Brussels, 2005), p. 28.

22 Arab Human Development Report 2003 (New York, United Nations Development Programme, 2003), p. 22.

23 Ibid., p. 23.

24 See Ian O. Lesser and Ashley J. Tellis, Strategic Exposure: Proliferation Around the Mediterranean (Santa Monica: Rand Publications, 1996).

25 Michele Dunne, Libya: Security is not Enough (Washington, DC: Carnegie Endowment for International Peace, 2004), p. 2.

26 Cited in 'Why Israel should not attack Iran', Defence Update: International Online Defence Magazine (12 December 2005), www.defense update.com/2005_12_01_defense-update_archive.html.

27 For details, see 'Egypt's budding nuclear programme', The Risk Report, 2:5 (1996), www.wisconsinproject.org/countries/egypt/nuke.html.

282005 Report by the Director General to the Board of Governors of the IAEA on the Implementation of the NPT Safeguards Agreement in the Arab Republic of Egypt, (Vienna:IAEA, 2005).

29 For details, see 'Egypt profile: nuclear chronology 2000-03', Nuclear Threat Initiative (October 2005), www.nti.org/e_research/profiles/Egypt/Nuclear/1697_1743.html.

30 For further background, see Claudiane Chevalier, Governance of the Mediterranean Sea:Outlook for the Legal Regime (Malaga: World Conservation Union Centre for Mediterranean Cooperation, 2005). 
31 Roberto Aliboni, 'Water as a factor of conflict: challenges around the Mediterranean Basin', L'acqua nei paesi arabi: il contesto giuridico, politico e storico-culturale Conference, Naples (22-24 February 2001).

32 Oceans and the Law of the Sea: Report of the Secretary General (New York: United Nations, 2005), p. 9.

33 Chevalier, Governance of the Mediterranean Sea, p. 45.

34 The Reagan Administration considered the Gulf of Sidra to be international waters and carried out naval exercises to challenge Libyan sovereignty over the Gulf.

35 Chevalier, Governance of the Mediterranean Sea, p. 45.

36 'Spanish offer on disputed Isle', CNN.com/World, 18 July 2002, http://edition.cnn.com/2002/WORLD/europe/07/18/spain.morocco/.

37 For the official Greek position, see www.mfa.gr/english/foreign_policy/europe southeastern/turkey/turkeys_claims_imia.html. For the Turkish counterclaims, see www.mfa.gov.tr/MFA/ForeignPolicy/Regions/EuropeanCountries/EUCountries/Greece/ GreeceLinks/the_Kardak_Dispute.htm.

38 Roberto Aliboni and Laura Guazzone, 'Democracy in the Arab countries and the West', Mediterranean Politics, 9:1 (Spring 2004), p. 87.

39 Ulla Holm, 'Algeria: France's untenable engagement', Mediterranean Politics, 3:2 (Autumn1998), pp. 104-14.

40 The US concluded free trade agreements with Israel (1985), Jordan (2000) and Morocco (2004) and an Egypt-Israel-US Trade Partnership in 2004.

41 For details of the Declaration, see www.knesset.gov.il/process/docs/venice_eng.htm. 42 Ambassador Wolfgang Ischinger, speech, 'Reconciliation instead of rifts', August 25 2005, info.org/relaunch/politics/speeches/082905.html.

43 Robert Kagan cited Charlemagne, 'Europe's Cassandra complex', The Economist (27 October 2005), p. 51.

44 For details, see Euro-Mediterranean Partnership, Conclusions of the Second EuroMediterranean Ministerial Conference (Malta, 1997).

45 See, for example, European Parliament Resolution on the Euro-Mediterranean Partnership (Brussels, 2005).

46 For details, see Reinvigorating European Union Actions on Human Rights and Democratisation with Mediterranean Partners: Strategic Guidelines (Brussels, 2005).

47 European Commission, Tenth Anniversary of the Euro-Mediterranean Partnership: A Work Programme for the Next Five Years (Brussels, 2005).

48 European Parliament Resolution on the Euro-Mediterranean Partnership.

49 Richard Youngs, 'Europe's uncertain pursuit of Middle East Reform', Carnegie Papers, 45 (June 2004), p. 8.

50 Ibid., p. 13.

51 EU Annual Report on Human Rights 2005 (Brussels, 2005) para. 3.7.

52 Madeleine Bunting, 'Regime change, European-style, is a measure of our civilisation', The Guardian (26 September 2005).

53 See Daniel Brumberg, 'Liberalization versus democracy: understanding Arab political reform', Carnegie Working Papers, 37 (May 2003), p. 6.

54 Ibid., p. 7.

55 See Marina Ottaway 'Democracy and constituencies in the Arab world', Carnegie Papers, 48 (July 2004), p. 4. 
56 For details of both programmes, see http://europa.eu.int/comm/external_relations/ euromed/rsp/rsp02_06.pdf

57 For full details, see Evaluation of the European Commission's Country Strategy for Egypt (La Hulpe, Belgium: MWH, 2004),

http://europa.eu.int/comm/europeaid/evaluation/reports/med/951647_vol1.pdf.

58 European Parliament Resolution on the Euro-Mediterranean Partnership.

59 The Action Plans, as well as the Commission's ENP Strategy Paper, are published on the Commission web-page, http://europa.eu.int/comm/world/enp/document_en.htm.

60 See EU Strategy against the proliferation of Weapons of Mass Destruction (Brussels: December 2003) 